\title{
Behavior of corrugated fibre cement sheets subjected to suction loads
}

\author{
Comportamiento de planchas onduladas de fibrocemento sometidas a cargas de succión \\ Julio Cesar Molina ${ }^{1 *} \quad$ Daniel Villas Bôas $^{1} \quad$ Murilo Negreli $^{1}$ \\ Alexandre Jorge Duarte de Souza ${ }^{1}$ \\ Recibido 3 de marzo de 2016, aceptado 27 de marzo de 2017 \\ Received: March 3, 2016 Accepted: March 27, 2017
}

\begin{abstract}
This paper presents two numerical models for the evaluation of the distribution of stresses in corrugated sheets of fibre cement subjected to uplift load. The numerical simulations, in this case, were made from three-dimensional models using the software SAP2000Nonlinear, version 7:42, which has as base the finite elements method (MEF). Corrugated sheets with thickness of $5 \mathrm{~mm}$ considering two different spans, i.e., $1100 \mathrm{~mm}$ and $1530 \mathrm{~mm}$ were evaluated. The sheets had the $2^{\text {nd }}$ and $5^{\text {th }}$ high waves fixed. The load of suction applied on the sheets was $10 \mathrm{kN} / \mathrm{m}^{2}$, and it was verified that the stresses on the sheets are distributed heterogeneously in a more complex pattern than for the bending stresses for vertical loads. The sheets suffer bending in transverse and longitudinal directions for the suction load applied, and the attachment points of sheets present concentration of stresses. The numerical results of the stresses showed good agreement with the results obtained from other researchers and these results can be used to predict the behavior of corrugated sheets of fibre cement subjected to wind load suction.
\end{abstract}

Keywords: Numerical simulation, fibre cement, stresses.

\section{RESUMEN}

Este artículo presenta dos modelos numéricos para evaluación de la distribución de tensión en planchas onduladas de fibrocemento sometido a una carga de succión. Las simulaciones numéricas en este trabajo, se hicieron a partir de modelos tridimensionales utilizando el software SAP2000Nonlinear, versión 7:42, que se basa en el método de elementos finitos (MEF). Se evaluó planchas onduladas con espesor de $5 \mathrm{~mm}$, teniendo en cuenta dos tramos diferentes, $1100 \mathrm{~mm}$ y $1530 \mathrm{~mm}$. Las planchas tuvieron las $2^{a}$ y $5^{a}$ olas altas fijas. La carga de succión aplicada en de las planchas fue de $10 \mathrm{kN} / \mathrm{m}^{2}$, fue encontrado que las tensiones de planchas en la succión se distribuyen heterogeneamente un estándar más complejo de lo que los esfuerzos de flexión obtenidos para cargas verticales. Las planchas sufren flexión en direcciones transversales y longitudinales en la carga de succión aplicada, y los puntos de fijación de las planchas tienen concentración de esfuerzos. Los resultados numéricos de las tensiones mostraron buena concordancia con los resultados de otros investigadores y estos resultados se pueden utilizar para predecir el comportamiento de planchas onduladas de fibrocemento sometidos a cargas de viento de aspiración.

Palabras clave: Simulación numérica, fibrocemento, tensiones.

\footnotetext{
1 Faculdade de Engenharia Industrial Madeireira da UNESP. Rua Geraldo Alckmin, 519. Vila N. Sra . de Fátima. CEP 18409-010. Itapeva, SP, Brasil.

E-mail: daniel@itapeva.unesp.br; murilo.negreli@grad.itapeva.unesp.br; alexandre@itapeva.unesp.br

* Autor de correspondencia: molina@itapeva.unesp.br
} 


\section{INTRODUCTION}

The mechanical behavior of corrugated sheets of fibre cement under loading $\mathrm{c} \Omega$ onditions in use has been little studied and there are few studies available in this topic.

In Brazil the experimental work development in the 80 s by the Institute of Technological Research (IPT) of São Paulo stands out considering corrugated sheets of fibre cement with different geometries in different spans and distributed loads for the simulation of the action of the wind of suction.

This study concluded that the sheets of fibre cement resisted well, safely and without the need of specific calculations to the wind, since the determinations as the mounting and fixing established by the manufacturers were followed [1].

Some numerical studies [2-3] developed abroad to evaluate the deflections in corrugated sheets considering concentrated and distributed loads stand out. Other international studies [4] discuss the risks of cracks in sheets of fibre cement subjected to wind load.

In practice, the suction wind is considered the action of higher risk for corrugated sheets used in roofing. It occurs in order to pull them out and only the points of attachment recommended by the manufacturer and the neighboring sheets of cover work prevent this pullout.

The aim of this work was to investigate from numerical simulations how the stresses are distributed in corrugated sheets of fibre cement from wind load, having the sheets the $2^{\text {nd }}$ and $5^{\text {th }}$ high waves fixed. The influence of neighboring sheets of cover was not considered in this study. For this specific case of load the deformations of the sheets were also evaluated in transverse and longitudinal directions. These results can help industries and researchers to solve the main problems related to this product. The strategy of the numerical modeling and the most important comments are also presented.

\section{MATERIAL AND METHODS}

The space among supports (span) has an important role in the behavior of corrugated sheets of fibre cement.
The recommended span for tests according to national standard [5] is of $1100 \mathrm{~mm}$ for sheets up to nominal thickness of $6 \mathrm{~mm}$. In this work, corrugated sheets of $1100 \mathrm{~mm}$ and $1530 \mathrm{~mm}$ spans were considered.

On the other hand, the wind loads have influence on the concentration of stresses at points of attachment of the corrugated sheets recommended by the manufacturer.

\section{CONFIGURATION OF THE ANALYZED SHEETS}

Corrugated sheets of fibre cement with the following configuration: Height: $51 \mathrm{~mm}$; Transverse width: $1100 \mathrm{~mm}$ and Thickness: $5 \mathrm{~mm}$, were analyzed.

Figure 1 shows the dimensions of cross section of the corrugated sheets and Figure 2 shows the nomenclature used for them.

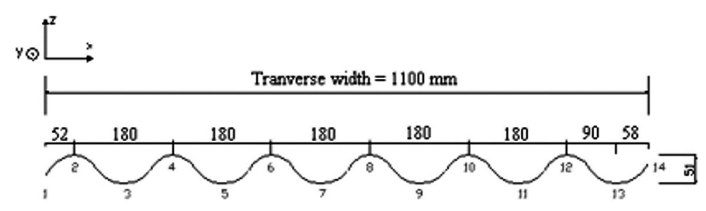

Figure 1. Cross section of the sheets considered in the numerical models.

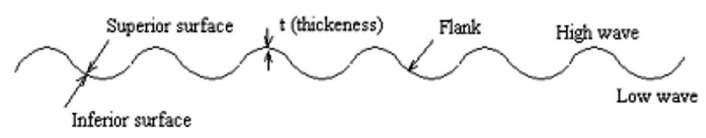

Figure 2. Nomenclature used for the corrugated sheets.

The corrugated sheets in the analyzed models were supported in two different spans having these sheets lateral balances. Figure 3 shows the support conditions for the sheets.

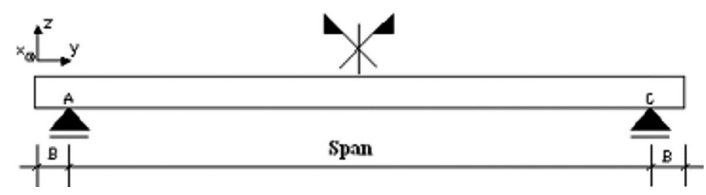

Figure 3. Support conditions for the sheet models analyzed.

Figure 4 shows the support conditions. The values of the longitudinal size as well as the balances 
used for the corrugated sheets that are related to the numerical models are indicated in Table 1. The corrugated sheets were fixed in the $2^{\text {nd }}$ and $5^{\text {th }}$ high waves in this case.

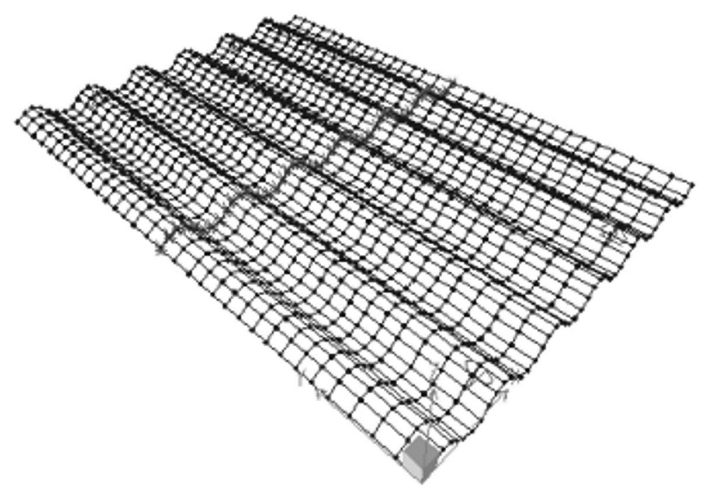

Figure 4. Support conditions admitted for the models.

Table 1. Support conditions and size of the sheets admitted for the models.

\begin{tabular}{|c|c|c|}
\hline $\begin{array}{c}\text { Size of the sheets } \\
(\mathbf{m m})\end{array}$ & $\begin{array}{c}\text { Support spans } \\
(\mathbf{m m})\end{array}$ & $\begin{array}{c}\text { Lateral balance B } \\
(\mathbf{m m})\end{array}$ \\
\hline 1100 & 1056.50 & 43.50 \\
\hline 1530 & 1476.25 & 53.75 \\
\hline
\end{tabular}

\section{LOAD CONDITIONS}

The load applied was equally distributed over the surface of the corrugated sheet as indicated in Figure 5.

In this case, the value of the applied load was 0.001 $\operatorname{MPa}\left(10 \mathrm{kN} / \mathrm{m}^{2}\right)$.

In practical applications, the value of the suction load, usually applied on the sheets by the wind, corresponds to $1 / 3$ of this value of load applied. The results presented in this work were compared with the results obtained by [1] and [8].

The value of $10 \mathrm{kN} / \mathrm{m}^{2}$ was used for comparison of the obtained results with the results from other researchers ${ }^{[1]}$ and also to verify how the stresses are distributed in sheets according to this specific type of applied load.

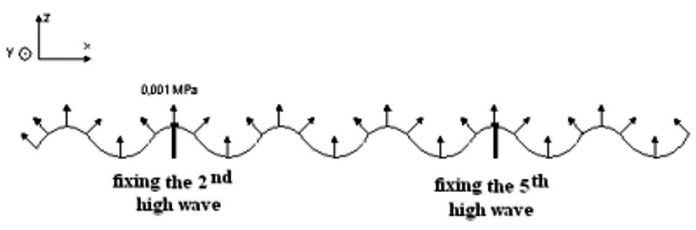

Figure 5. Support conditions ( $2^{\text {nd }}$ and $5^{\text {th }}$ high wave attachment) with suction load distributed over the upper surface of the sheet.

\section{BOUNDARY CONDITIONS}

To simulate the action of wind in corrugated sheets considering the lengths indicated in Table 1 and an applied load of $0.001 \mathrm{MPa}$, over the upper surface of the sheet, the following boundary conditions were considered:

a) Restrain of the displacements in the $\mathrm{x}$ and $\mathrm{z}$ directions in the sections of support;

b) Restrain of the displacement y at points located in the central section.

Figure 6 shows the details of boundary conditions used for the corrugated sheets in the analyzed models.

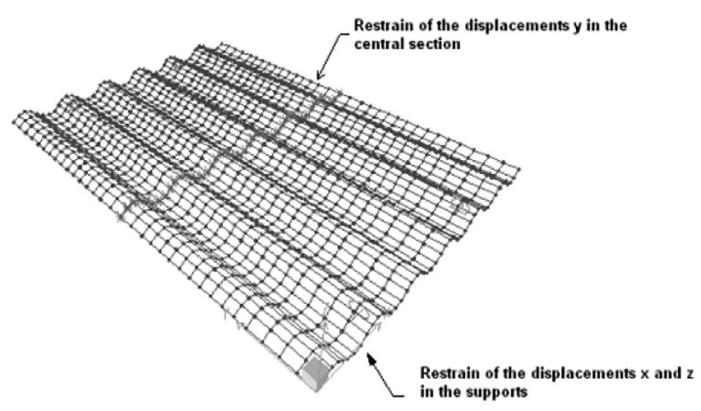

Figure 6. Displacement restraint in the supports and in the central section of the sheet.

\section{MESH OF FINITE ELEMENTS}

The mesh was discretized in a total of 1152 elements for the $1100 \mathrm{~mm}$ span sheet and 1536 elements for the $1530 \mathrm{~mm}$ span sheet.

Mesh refinement was made using the SAP2000 Nonlinear6 software, version 7:12, which has as base the finite elements method (FEM). However, there are specific computer programs to construct complex meshes [7]. 
In the models, shell elements in the mesh composition were used. The shell element has four nodes with six degrees of freedom per node, being three translations and three rotations. Each shell element was built having the same orientation for the quadrilaterals, which formed each shell element. In the SAP2000Nonlinear, the local axe 3 is oriented in perpendicular direction to the element surface.

This way the local axes 1,2 and 3 of all shell elements were used with the same orientation facilitating the mesh refinement of finite elements and subsequently the analysis of the results.

Figure 7 shows the orientation of the local axes in the sheets and some details of the mesh of finite elements.

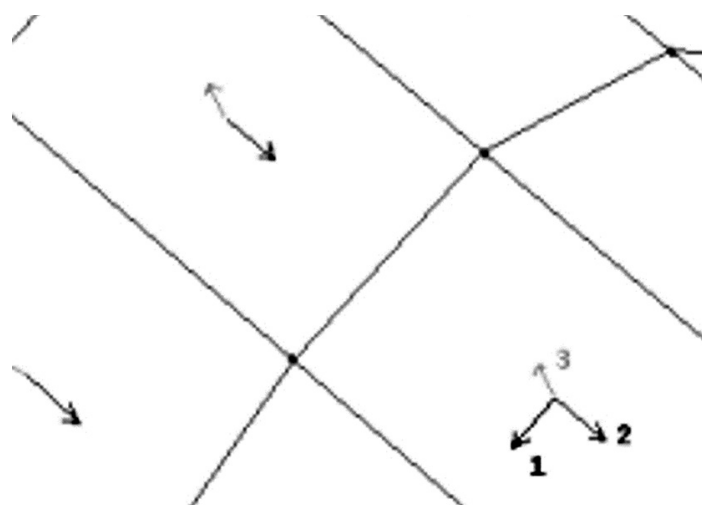

Figure 7. Orientation of the local axes 1,2 and 3 in shell elements and details of mesh of finite elements.

\section{ANALYSIS OF THE MODELS}

The models were developed considering the physical linearity of the material (the stresses are proportional to the strains) and geometric non-linearity of the sheets (deformed configuration). Isotropic behavior for the material in the composition of the sheets was considered.

The elastic properties of the sheets considered for the models were:

- Module of elasticity (E): 9000 N/mm² (9000 $\mathrm{MPa}$;;

- Poisson ratio (v): 0.2 (typical value for the fibre cement used in the corrugated sheets).
According to some researchers $[8,9]$ the most suitable elasticity module to use in numerical models is that obtained from the direct tests of tension instead of bending.

\section{STRESSES AND DEFORMATIONS EVALUATED IN THE MODEL}

To the considered load of $10 \mathrm{kN} / \mathrm{m}^{2}$, the analysis of the stresses with larger potential to cause damage to the component was evaluated. The stresses with this potential are the followings:

Transverse stress $\sigma_{22}$ (occur in the x direction); Longitudinal stress $\sigma_{11}$ (occur in the y direction).

The values of the main stresses, $\sigma_{22}$ and $\sigma_{11}$, were verified in the finite elements localized in the central section of the sheet, as indicated in Figures 8 and 9.

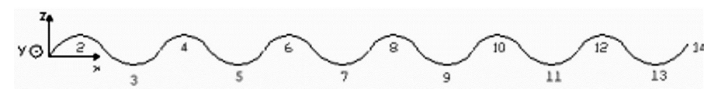

Figure 8. Points of the sheets where maximum stresses $\sigma_{22}$ and $\sigma_{11}$ take place.

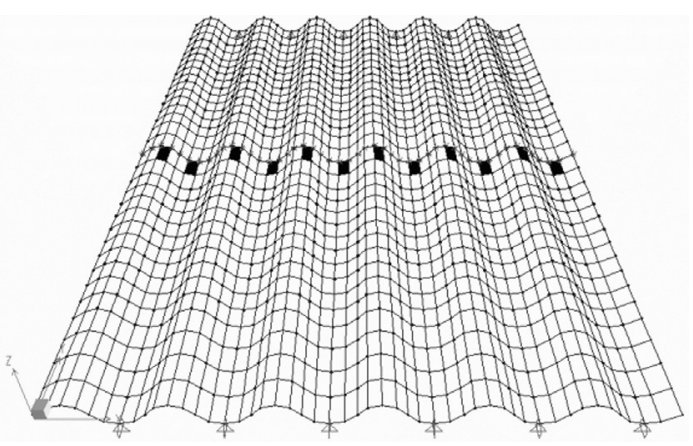

Figure 9. Details of the elements in the central area of the sheet where maximum stresses $\sigma_{22}$ and $\sigma_{11}$ take place.

In this study, the behavior of the deformed configurations in transverse and longitudinal directions of the corrugated sheets was also analyzed.

\section{RESULTS}

The results of longitudinal stresses $\sigma_{11}$ obtained from the numerical simulations are shown in Figures 10 and 11. 
The stress values for the sheets in the points showed in Figure 10 are indicated in Tables 2 and 3.

\section{LONGITUDINAL STRESSES}

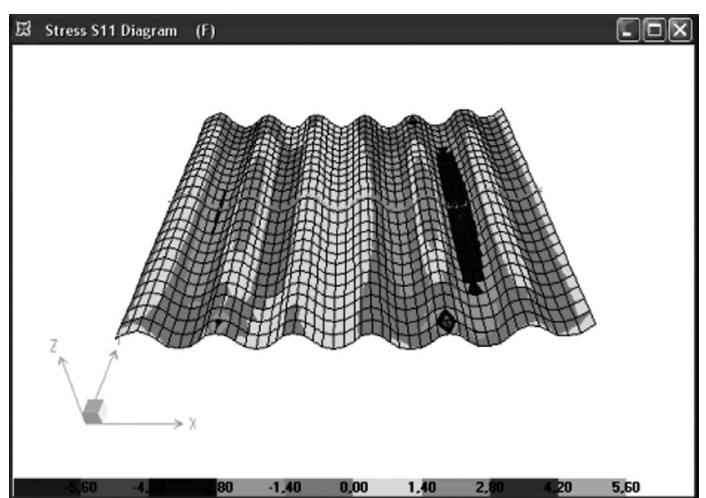

Figure 10. Distribution of the longitudinal stresses $\sigma_{11}$, in the model of $1100 \mathrm{~mm}$ span sheet, on the upper surface of the high waves.

Table 2. Values of longitudinal stresses in the central area of the $1100 \mathrm{~mm}$ span sheet.

\begin{tabular}{|c|c|c|c|c|c|}
\hline \multicolumn{7}{|c|}{$\begin{array}{c}\sigma_{11} \text { (MPa) on the upper surface } \\
\text { of the high waves (tension) }\end{array}$} \\
\hline 2 & 4 & 6 & 8 & 10 & 12 \\
\hline 1.26 & 2.43 & 0.55 & 0.52 & 2.66 & 0.79 \\
\hline
\end{tabular}

Table 3. Values of longitudinal stresses in the central area of the $1100 \mathrm{~mm}$ span sheet.

\begin{tabular}{|c|c|c|c|c|c|}
\hline \multicolumn{5}{|c|}{$\begin{array}{l}\sigma_{11} \text { (MPa) on the lower surface } \\
\text { of the low waves (compression) }\end{array}$} \\
\hline 2 & 4 & 6 & 8 & 10 & 3 \\
\hline 1.26 & 2.43 & 0.55 & 0.52 & 2.66 & 2.48 \\
\hline
\end{tabular}

The stress values for the sheets in the points showed in Figures 11 are indicated in Tables 4 and 5.

Table 3. Values of longitudinal stresses in the central area for the $1530 \mathrm{~mm}$ span sheet.

\begin{tabular}{|c|c|c|c|c|c|}
\hline \multicolumn{7}{|c|}{$\begin{array}{c}\sigma_{11} \text { (MPa) on the upper surface } \\
\text { of the high waves (tension) }\end{array}$} \\
\hline 2 & 4 & 6 & 8 & 10 & 12 \\
\hline 2.78 & 5.45 & 1.70 & 1.62 & 6.65 & 2.35 \\
\hline
\end{tabular}

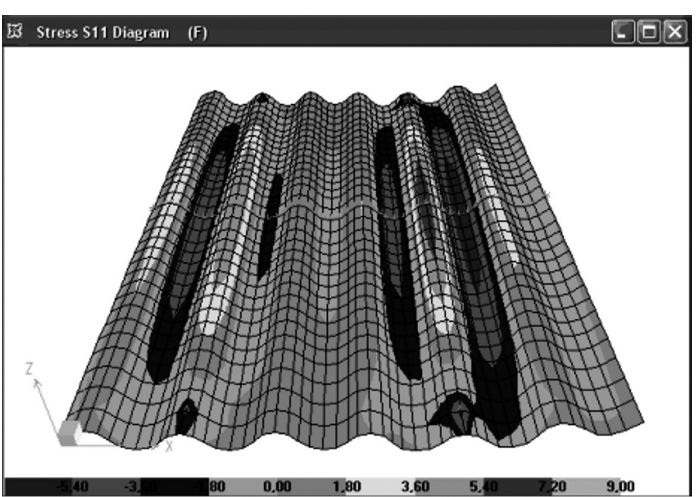

Figure 11. Distribution of the longitudinal stresses $\sigma_{11}$, in the model of sheet with span of $1530 \mathrm{~mm}$, in the upper surface of the high waves.

Table 4. Values of longitudinal stresses in the central area for the $1530 \mathrm{~mm}$ span sheet.

\begin{tabular}{|c|c|c|c|c|c|}
\hline \multicolumn{7}{|c|}{$\begin{array}{c}\sigma_{11} \text { (MPa) on the upper surface } \\
\text { of the high waves (tension) }\end{array}$} \\
\hline 3 & 5 & 7 & 9 & 11 & 13 \\
\hline 5.05 & 3.28 & 1.92 & 4.31 & 5.48 & 1.30 \\
\hline
\end{tabular}

\section{TRANSVERSE STRESSES}

The results of transverse stresses $\sigma_{22}$ obtained from the numerical simulations are shown in Figures 12 and 13. The stress values for the sheets in the points showed in Figure 12 are shown Tables from 5 to 8 and the stress values for the sheets in the points showed in Figures 13 are shown Tables from 9 to 12.

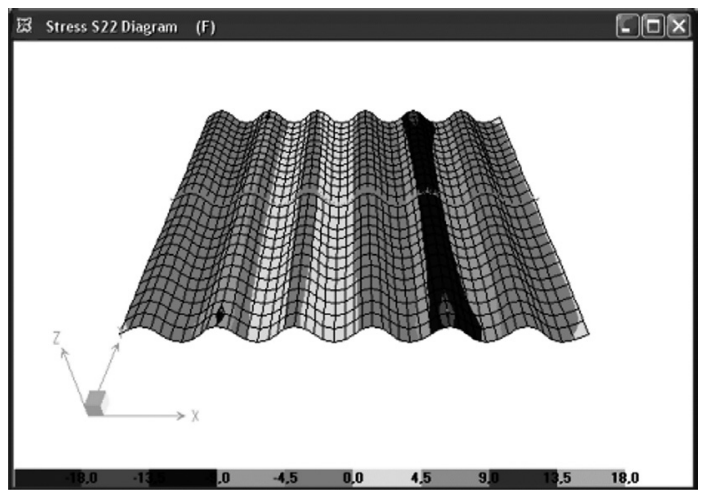

Figure 12. Distribution of the transverse stresses $\sigma_{22}$, in the model of $1100 \mathrm{~mm}$ span sheet, on the upper surface of the high waves. 
Table 5. Values of transverse stresses in the central area for the $1100 \mathrm{~mm}$ span sheet.

\begin{tabular}{|c|c|c|c|c|c|}
\hline \multicolumn{5}{|c|}{$\begin{array}{c}\sigma_{22} \text { (MPa) on the upper surface } \\
\text { of the high waves (compression) }\end{array}$} \\
\hline 2 & 4 & 6 & 8 & 10 & 12 \\
\hline 0.77 & 5.16 & 1.11 & 3.48 & 11.25 & 3.98 \\
\hline
\end{tabular}

Table 6. Values of transverse stresses in the central area for the $1100 \mathrm{~mm}$ span sheet.

\begin{tabular}{|c|c|c|c|c|c|}
\hline \multicolumn{6}{|c|}{$\begin{array}{c}\sigma_{22} \text { (MPa) on the upper surface } \\
\text { of the low waves (tension/compression) }\end{array}$} \\
\hline 3 & 5 & 7 & 9 & 11 & 13 \\
\hline-2.87 & 1.91 & 3.45 & -3.68 & -7.17 & -0.99 \\
\hline
\end{tabular}

Table 7. Values of transverse stresses in the central area for the $1100 \mathrm{~mm}$ span sheet.

\begin{tabular}{|c|c|c|c|c|c|}
\hline \multicolumn{7}{|c|}{$\begin{array}{c}\sigma_{22} \text { (MPa) on the lower surface } \\
\text { of the high waves (tension) }\end{array}$} \\
\hline 2 & 4 & 6 & 8 & 10 & 12 \\
\hline 0.67 & 5.54 & 1.34 & 3.62 & 11.58 & 3.84 \\
\hline
\end{tabular}

Table 8. Values of transverse stresses in the central area for the $1100 \mathrm{~mm}$ span sheet.

\begin{tabular}{|c|c|c|c|c|c|}
\hline \multicolumn{6}{|c|}{$\sigma_{22}$ (MPa) on the lower surface } \\
of the low waves (tension/compression)
\end{tabular}

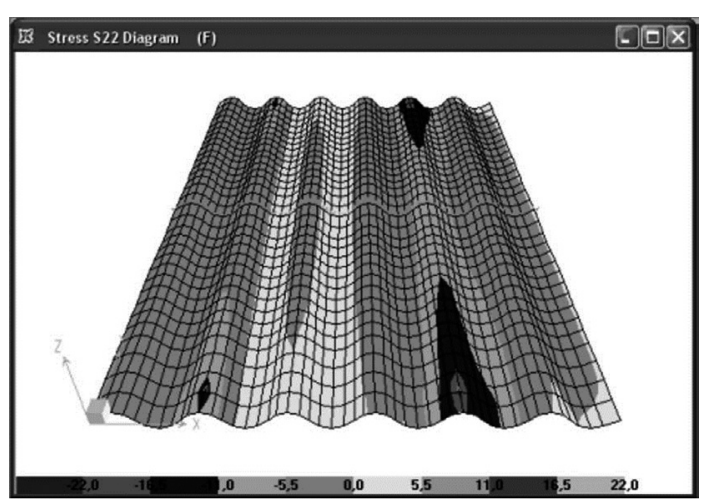

Figure 13.Distribution of the transverse stresses $\sigma_{22}$, in the model of $1530 \mathrm{~mm}$ span sheet, on the upper surface of the high waves.
Table 9. Values of transverse stresses in the central area for the $1530 \mathrm{~mm}$ span sheet.

\begin{tabular}{|c|c|c|c|c|c|}
\hline \multicolumn{5}{|c|}{$\begin{array}{c}\sigma_{22} \text { (MPa) on the upper surface } \\
\text { of the high waves (compression) }\end{array}$} \\
\hline 2 & 4 & 6 & 8 & 10 & 12 \\
\hline-0.84 & -4.55 & -1.75 & -3.88 & -9.25 & -4.75 \\
\hline
\end{tabular}

Table 10. Values of transverse stresses in the central area for the $1530 \mathrm{~mm}$ span sheet.

\begin{tabular}{|c|c|c|c|c|c|}
\hline \multicolumn{6}{|c|}{$\begin{array}{c}\sigma_{22} \text { (MPa) on the upper surface } \\
\text { of the low waves (tension/compression) }\end{array}$} \\
\hline 3 & 5 & 7 & 9 & 11 & 13 \\
\hline-2.53 & 1.16 & 2.29 & -3.38 & -5.56 & -1.18 \\
\hline
\end{tabular}

Table 11. Values of transverse stresses in the central area for the $1530 \mathrm{~mm}$ span sheet.

\begin{tabular}{|c|c|c|c|c|c|}
\hline \multicolumn{7}{|c|}{$\begin{array}{c}\sigma_{22} \text { (MPa) on the lower surface } \\
\text { of the high waves (tension) }\end{array}$} \\
\hline 2 & 4 & 6 & 8 & 10 & 12 \\
\hline 0.64 & 4.51 & 2.04 & 3.44 & 9.83 & 4.44 \\
\hline
\end{tabular}

Table 12. Values of transverse stresses in the central area for the $1530 \mathrm{~mm}$ span sheet.

\begin{tabular}{|c|c|c|c|c|c|}
\hline \multicolumn{6}{|c|}{$\begin{array}{c}\sigma_{22} \text { (MPa) on the lower surface } \\
\text { of the low waves (tension/compression) }\end{array}$} \\
\hline 3 & 5 & 7 & 9 & 11 & 13 \\
\hline 2.80 & -1.16 & -2.22 & 3.85 & 6.04 & 1.30 \\
\hline
\end{tabular}

The intensification of the transverse stresses on the attached high waves ( $2^{\text {nd }}$ and $5^{\text {th }}$ high waves) is due to the evaluation of the sheet in the isolated situation, since it does not suffer the influence of the surrounding sheets that would tend to reduce the deformations and consequently the intensity of stresses in the corrugated sheets.

The most intense stresses in the transverse direction occur in the fixed waves and increase near the points of attachment, and these areas have the highest probability of failing.

The transverse stresses are distributed on the sheets in a complex way, where compression occurs on the upper surface of the high waves and tension on 
the lower surface. On the other hand, for the low waves, compression and tension stresses occur on the upper surfaces of the sheets.

\section{LONGITUDINAL DEFORMATIONS}

The longitudinal deformation of high wave of sheet 10 , i. e., $5^{\text {th }}$ high wave, and the global deformed position of the sheet are presented in Figures 14 and 15 in the follow, respectively.

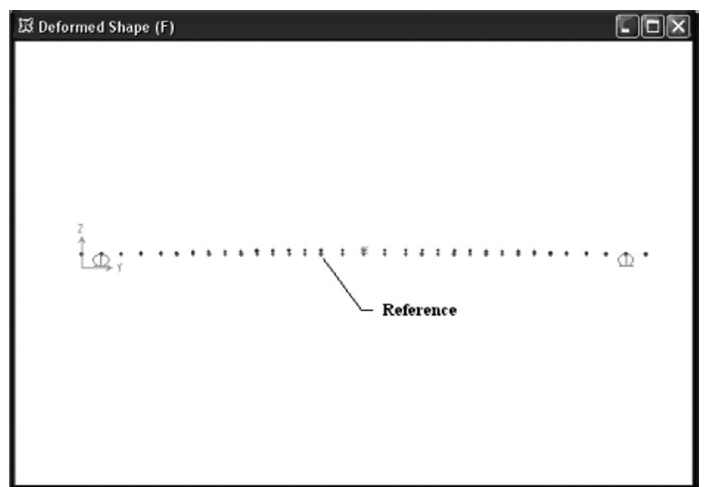

Figure 14. Longitudinal deflection of the $1530 \mathrm{~mm}$ span sheet: deformed position of high wave 10.

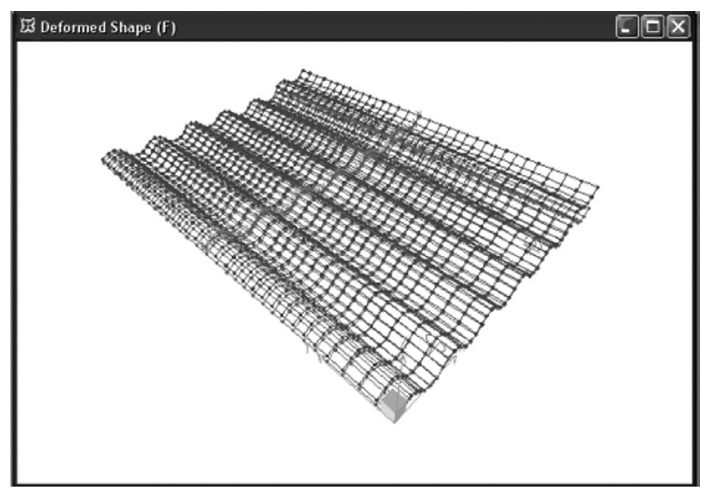

Figure 15. Longitudinal deflection of the $1530 \mathrm{~mm}$ span sheet: global deformed position of the sheet.

\section{TRANSVERSE DEFORMATIONS}

Figure 16 shows the way in which the sheets are deformed in the transverse direction according to distributed suction load, intensifying the stresses so that compression occur on the upper surface and tension on the lower surface of the high waves, especially on the fixed waves.
The occurrence of cracks in corrugated sheets without asbestos has been reported in the literature [4], since the cause of the cracks is related to stresses generated by the action of wind.

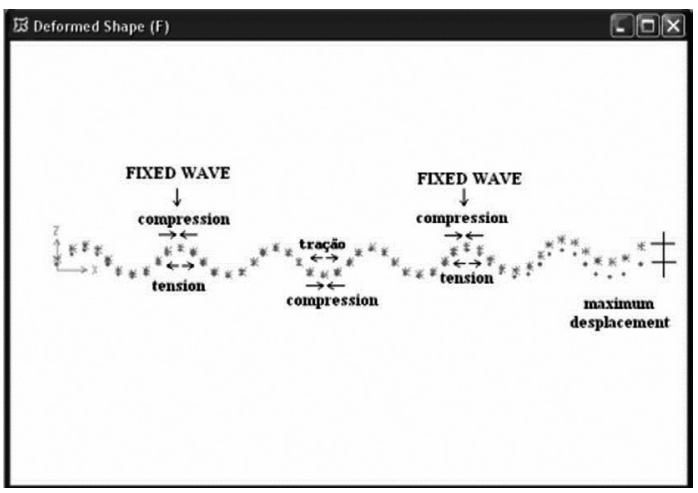

Figure 16. Deformed position of the $1530 \mathrm{~mm}$ length sheet subjected to suction load of 0.001 MPa.

Figure 17 shows the global view of the transversal deformed subjected to suction load of $0.001 \mathrm{MPa}$.

All the values of stress obtained from the numerical simulations were compared with the results from other researchers ${ }^{[1]}$ and these results showed a good agreement.

Is important to say that [1] developed a extensive work about the effect of different loads in corrugated fibre cement sheets

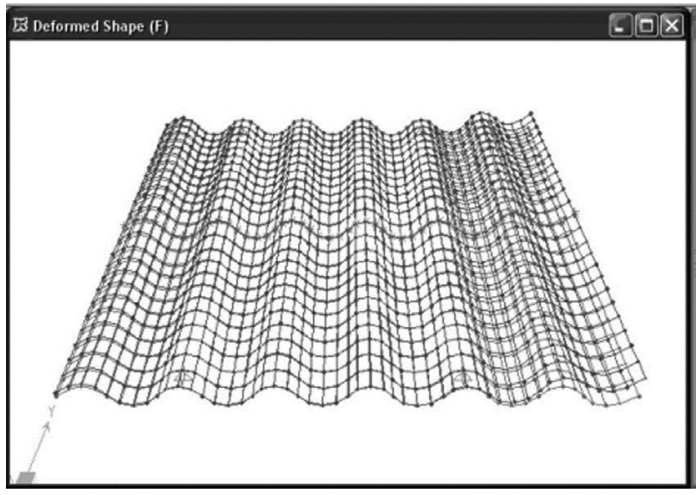

Figure 17. Global view of the transversal deformed of the $1530 \mathrm{~mm}$ length sheet subjected to suction load of $0.001 \mathrm{MPa}$. 


\section{CONCLUSIONS}

For the specific conditions of fixing and loading used in the simulations of suction load, the sheets suffer bending in both transverse and longitudinal directions.

For suction loads, the stresses are distributed heterogeneously in a more complex pattern than for the bending stresses with vertical loads.

The transverse stresses tend to lift the lateral parts of the sheet, since the most intense stresses occur in the fixed waves. In this case, the intensities of the stresses increase in direction of the attachment points, and these points are those with most likelihood to fail.

Differently from bending tests with vertical loads, in the suction loads the longitudinal stresses are predominantly of compression in the low waves, and of tension in the high waves.

The most intense stress occurs in the central area of the sheet, on the attached waves $\left(2^{\text {nd }}\right.$ and $5^{\text {th }}$ high waves).

\section{ACKNOWLEDGEMENTS}

The authors gratefully acknowledge the technical support of LAMEM/EESC/USP, College of Zootechny and Food Engineering/USP and Polytechnic School/USP.

\section{REFERENCES}

[1] C.M.C. Dias. "Fibre cement with functional gradation”, pp. 1-173.2011. February, 2014:URL: file://C:/Users/Administrador/Downloads/ Tesel_Cleber_Marcos_Dias\%20(2).pdf
[2] A. Baroonian. "Theorical and experimental investigation of fibre cement corrugated sheeting under load", pp. 1-285. 1986. February, 2014: URL: http://hdl.handle. net/10068/638719

[3] A. Baroonian, J. G, Keer. "Finite element modeling of fibre cement corrugated sheeting". Composites. Vol. 19, Issue 2, pp. 139-134, March, 1988. DOI: 10.1016/ 0010-4361(88)90724-0.

[4] K.F. Hansen, B.D. Stang. "Safety against formulation of through cracks of profiled fibre-reinforced cement sheets for roofing". Construction and Building Materials. Vol. 23, Issue 1, pp. 334-339, January, 2009. DOI: doi:10.1016/j.conbuildmat.2007.12.001.

[5] ASSOCIAÇÃO BRASILEIRA DENORMAS TÉCNICAS - 5210-2: Corrugated sheet of fibre cement without asbesto and their accessories Part 2: Tests. ABNT, Rio de Janeiro. 2005.

[6] SAP 2000 NonLinear, versão 7: 42 Documentation.

[7] J.C. Molina. "Analysis of the dynamic behavior of the connectors formed by bonded-in steel rods for log-concrete composite deck bridges", pp. 1-240. 2008. February, 2014: URL: http://web.set.eesc. usp.br/static/data/producao/2008DO_ JulioCesarMolina.pdf.

[8] J.C. Molina, J. Fiorelli, H. Savastano Junior. "Analysis of the stresses in corrugated sheets under bending". Materials Research. Vol. 17, No 2, pp. 338. March/April, 2014.

[9] J.C. Molina, C. Calil Junior. "Estratégia de modelagem numérica considerando diferentes modelos de ruptura para os materiais". Materials Research. Vol. $17 \mathrm{~N}^{\circ}$ 2, pp. 256266. March/April, 2014. 